\title{
An overview of trace elements in soils of Keana-Awe Brine-Fields, Middle Benue Trough, Nigeria
}

\author{
Adamu Sallau, Abuh Momoh, Mimonitu Opuwari, Segun Akinyemi and Uriah Lar
}

\begin{abstract}
The objective of this study was to determine the concentration of trace elements in soils of Keana-Awe brine-fields. Composite soil samples were randomly collected at a depth of 0-15 $\mathrm{cm}$ and were analysed for molybdenum, zinc, arsenic, lead, cobalt, chromium, copper, barium and nickel using Inductively Coupled Plasma Mass Spectroscopy (ICP-MS). Quantification of the degree of soil contamination by these trace elements was carried out using the enrichment factor (EF) and the geo-accumulation index (Igeo). The data were subjected to principal component analysis (PCA). The average concentrations were $1.56 \mathrm{ppm}$ molybdenum, $1116.42 \mathrm{ppm}$ zinc, $23.80 \mathrm{ppm}$ arsenic, $71.40 \mathrm{ppm}$ lead, $17.64 \mathrm{ppm}$ cobalt, 237.35 ppm chromium, 24.16 ppm copper, $254.67 \mathrm{ppm}$ barium and $143.71 \mathrm{ppm}$ nickel. Cobalt, nickel and chromium showed positive loadings in component 1 with a total variance of $29.56 \%$. Zinc, copper and lead showed positive loadings in component 2 with a total variance of $18.79 \%$, while copper showed negative loading in component 3 with a total variance of $14.79 \%$. Considering the concentration of trace elements in the soils and statistical analyses, we conclude that soils of the study area were severely enriched in molybdenum, cobalt, chromium, copper, barium, nickel, while arsenic and zinc are in excessive concentrations in the soils. These trace elements could have originated from geogenic and anthropogenic sources.
\end{abstract}

\section{Introduction}

Trace elements in soils are derived from both natural (geogenic) and anthropogenic sources. The natural sources are derived from the parent materials through the processes of erosion, transportation and deposition. The contribution of trace elements from anthropogenic sources in soils could be much higher than the contribution from natural sources (Zhuang et al., 2013). The anthropogenic inputs are associated with mining; industrialisation; waste disposal; smelting; vehicular traffic; agricultural activities such as fertiliser and herbicide application on farmland and long-term application of sewage sludge on agricultural land (Ahmed \& Gani, 2010). The natural concentration of trace elements in soils derived from their parent materials is not sufficient to cause any adverse harm to human health (Guo et al., 2013). However, anthropogenic sources can greatly increase trace element concentration in soils and when they are taken up by crops, and in turn consumed by human beings, could pose a risk to human health (Guo et al., 2013). Trace element contamination in soils 
has attracted so much attention in recent years because of the hazard it poses to human health (Loska et al., 2004). Anomalous concentration of trace elements in agricultural soils have been of great concern to several countries of the world and organisations such as the Food and Agricultural Organization of the United Nations (FAO) due to food safety issues, potential health risks and its detrimental effects on soil ecosystems (Mapanda et al., 2005). Soil contamination by trace elements is on the increase on a daily basis and this is of great concern to all living organisms and the entire ecosystem. Research has shown that if the trace element concentrations in soils of any locality are above normal, they may have a detrimental effect on the environment due to their toxicity and accumulation in microorganisms, plants, animals and humans (Krishna et al., 2011). Trace elements such as lead, mercury, arsenic and cadmium are toxic and poisonous to human beings, while some trace elements such as zinc, copper, iron and manganese are essential for metabolic functioning in small amounts but in excess, they become toxic (Zhuang et al., 2013). Excessive dietary ingestion of trace elements could lead to a series of human health disorders, which include decreased immunological defences, impaired psychosocial behaviour, disabilities associated with malnutrition and gastro-intestinal disorders (Zhuang et al., 2013). The Keana-Awe axis of the Middle Benue Trough is the largest lead-zinc, baryte and copper mining district in Nigeria. These areas support an important agricultural industry that accounts for $30 \%$ of natural food production (Sallau, 2015). There were several mining companies in the area that were involved in exploitation and processing of these mineral resources. At the time of this study, 10 artisanal mining firms were actively extracting lead and zinc from the locality. Tailings, acid mine drainage (AMD) and gangues from processing of these minerals were indiscriminately disposed in the area. The objective of this study was to determine the trace element concentrations in the soils of the Keana-Awe Brine-Fields, in order to identify potential harmful elements that could pose a health risk to inhabitants of the area.

\section{Study area}

The Keana-Awe Brine-Fields falls within the Middle Benue region of Nigeria (Figure 1). Physiographically, the area is flat, gently undulating and certain areas were interrupted by broad ridges such as Aloshi Ridge at Keana, the Azara barite quartzite ridge at Azara-Wuse axis, all ranging between 230 and $280 \mathrm{~m}$ above sea level (Sallau, 2015). These ridges serve as river divides for some streams and rivers within the study area. Rivers Asuku, Wuse, Ome and Okpobi are the major rivers in the area. These rivers form a dendritic drainage pattern in the area as they finally empty into the River Benue at the southeastern edge of the area (Sallau, 2015). The area is characterised by a tropical sub-humid climate with two distinct seasons - dry and wet. The dry season starts from November to April, and the wet season is from May to October. 


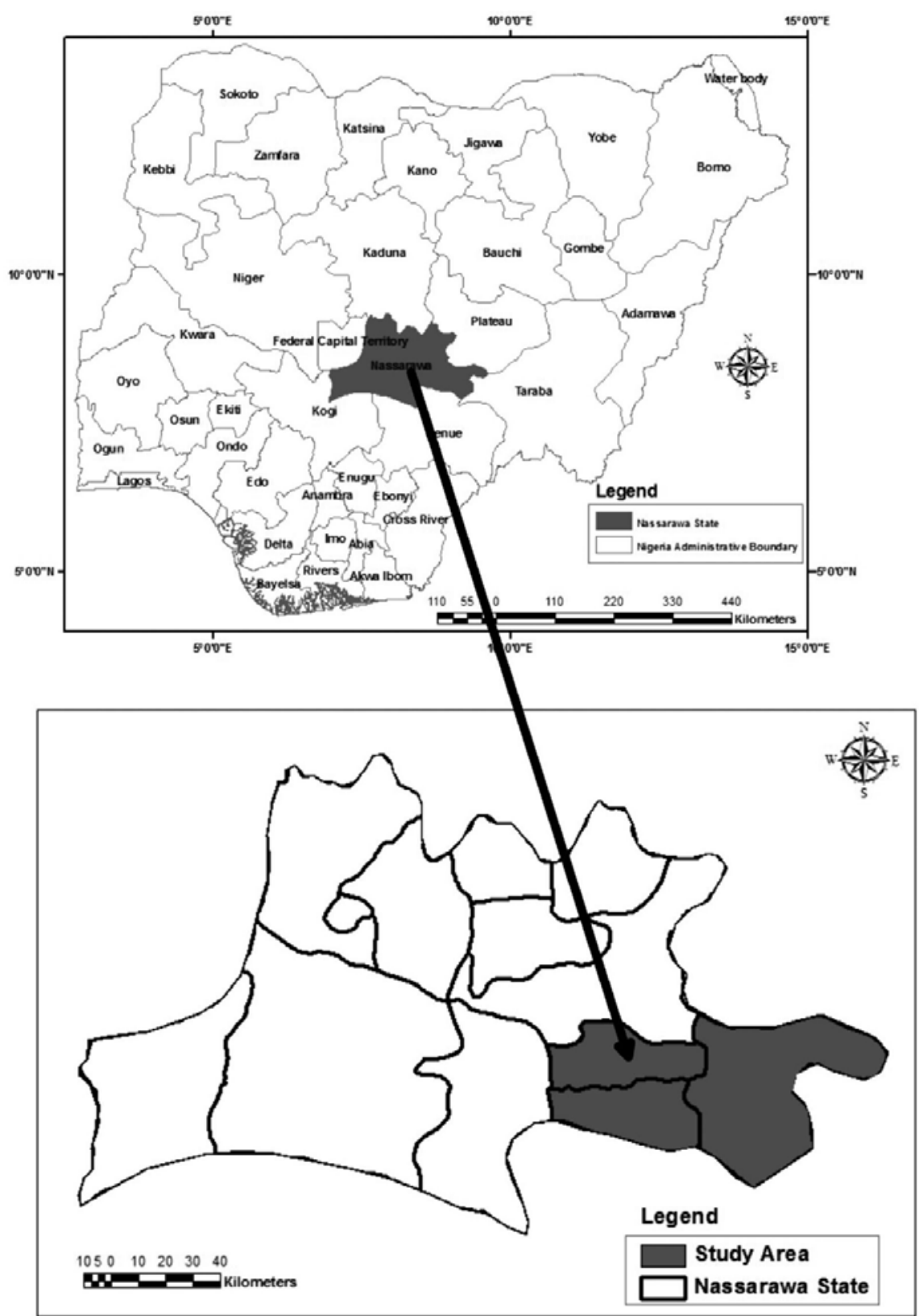

Figure 1. Map of the study area, Keana-Awe brine-fields, Middle Benue Trough, Nigeria

Annual rainfall ranges between 1100 and 2000mm, Temperatures are generally high during the day, most especially between the months of March and April. The average monthly temperatures in the area range between 20 and $34^{\circ} \mathrm{C}$ (Sallau, 2015).

\section{Geology}

The Keana-Awe Brine-Fields are underlain by five sedimentary formations (Figure 2). The oldest formation is the Asu River Formation; it consists of olive-green to grey dark and pinkish micaceous siltstones, shales, mudstones and subordinate clays (Offodile, 1976). 

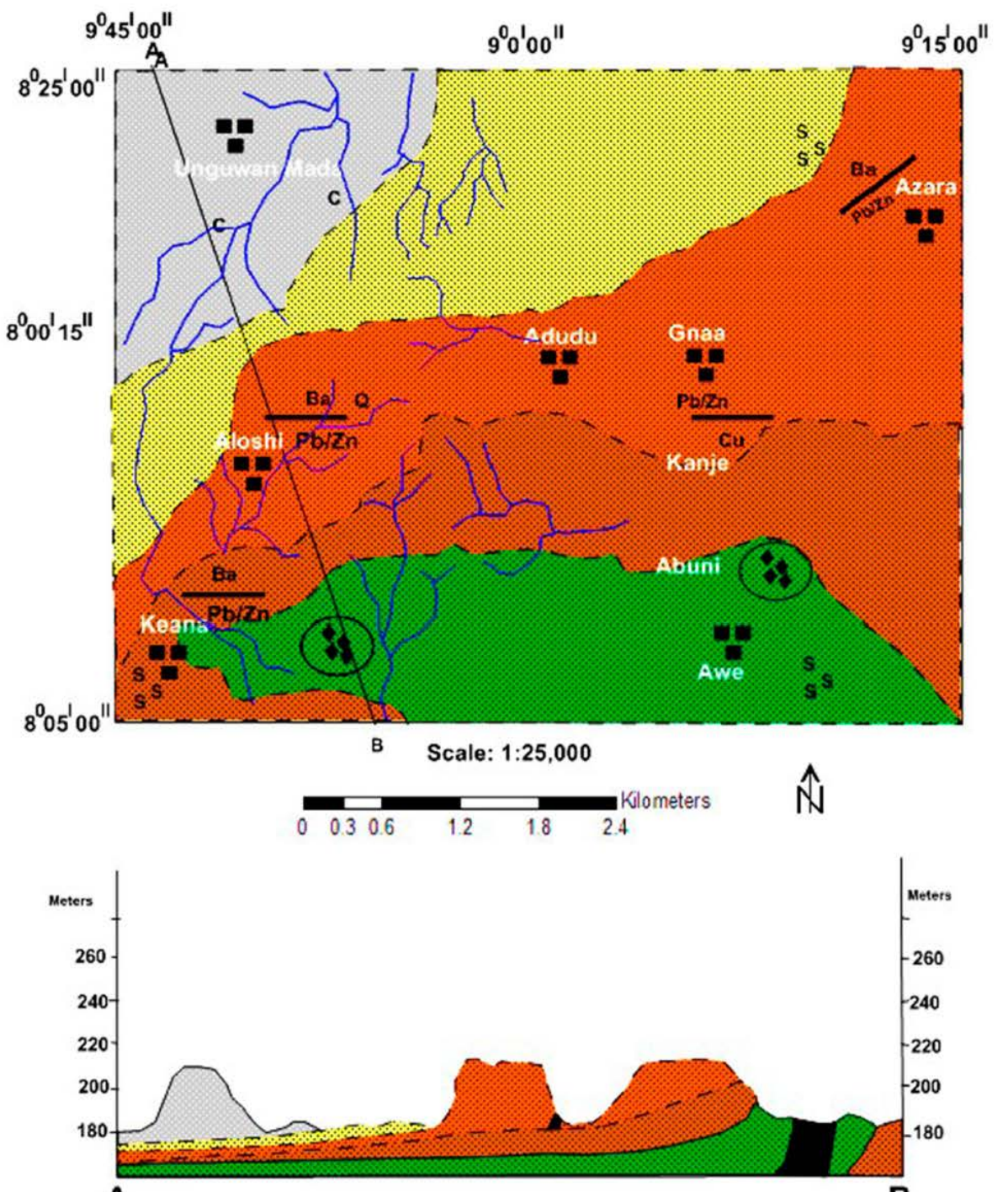

A

GEOLOGICAL CROSS SECTION

B

\section{LEGEND}

Agwu Formation-(Shale)
Ezeaku Formation-(Shale-Sandstone-Mud Rock)
Keana Formation-(Sandstone)
Asu Formation-(Shale-sandstone)
$\mathrm{S}$ S Briner Formation-(Shale-Siltstone)
Ba-Baryte
Cu-Copper
Q-Quartz
C-Coal

Figure 2. Geological map of the study area, Keana-Awe brine-fields, Middle Benue Trough, Nigeria. 
The outcrops were exposed at the eastern part of Keana and at the southern part of the Ugir River. Overlying the Asu River Formation is the Awe Formation which consists of flaggy, medium coarse-grained sandstones with interbedded carbonaceous shales from which brines issue out copiously (Nwajide, 2013). Its thickness was estimated at about $1000 \mathrm{~m}$ and it was speculated that Awe brines were derived from mineralising solutions that are associated with Benue lead zinc mineralisation (Nwajide, 2013). Preceding the Awe Formation is the Keana Formation; which consists of poorly sorted, fine-to-coarse grained sandstone with subordinate siltstone and shale (Nwajide, 2013). Overlying the Keana Formation is the Ezeaku Formation; the formation was described as a sequence of hard, dark and grey to black flaggy calcareous shales, siltstones and sandstones (Sallau, 2002). At the topmost of the formations is the Awgu Formation. It is made up of shales, clayey shales and shelly limestone (Sallau, 2002). Coal seams were found within the formation around the ObiAgwatashi area (Sallau, 2002).

\section{Materials and Methods \\ Sample collection and preparation}

Soil samples $(\mathrm{n}=40)$ were collected from $0-15 \mathrm{~cm}$ depth. The locations were chosen to provide a good representation of the entire area (Table 1). Soil samples were collected in the months of February and March 2014. These correspond to when the dry season was at its peak, when trace elements in soils were at their optimal levels. The soil samples were collected with the aid of a stainless steel hand auger and then stored in polyethylene bags. After sampling, soil samples were dried in an oven at $30^{\circ} \mathrm{C}$. The dried samples were disaggregated in a porcelain mortar and sieved through a $<0.075 \mathrm{~mm}$ sieve to remove plant roots and other debris. Two grammes of each powdered soil sample was weighed using an analytical balance into a Teflon crucible and aqua regia $\{\mathrm{HCl}+\mathrm{HNO} 3+\mathrm{HClO} 4,(3: 2: 1)\}$ was added to it. The solution was placed on a hot plate and heated at $250^{\circ} \mathrm{C}$ until dry. The crucible containing the sample was allowed to cool; $2 \mathrm{ml}$ of $4 \mathrm{M} \mathrm{HCl}$ was added and then diluted with $10 \mathrm{ml}$ of deionised water. The solution was filtered with the use of an ashless filter paper into a flat bottomed flask and analysed for a number of trace elements by Inductively Coupled Mass Spectrometry (ICP-MS) in the Geochemistry Laboratory of the Geology and Mining Department, University of Jos, Nigeria. The detection limit of the analytical tool was $0.01 \mathrm{ppm}$. The precision of the analytical results was evaluated by comparing with certified values of analysed reference materials which were within the quoted confidence limits. 


\begin{tabular}{|c|c|c|c|c|}
\hline Sample location & Location & Sample description & Lat $\left({ }^{\circ} \mathrm{N}\right)$ & Long $\left({ }^{\circ} \mathrm{E}\right)$ \\
\hline SS-1 & Keana - Obi Rd & Brown sandy soil & 080957.7 & 0084752.7 \\
\hline SS-2 & Borsta & Reddish brown, ferrugenised soil & 080512.7 & 0084707.0 \\
\hline SS-3 & Keana - Makurdi Rd & Brownish clayey soil & 080545.0 & 0084720.2 \\
\hline SS-4 & Keana - Makurdi Rd & Brownish clayey soil & 080614.6 & 0084728.6 \\
\hline SS-5 & Keana - Makurdi Rd & Slightly ferugenised reddish brown soil & 080646.1 & 0084737.4 \\
\hline SS-5 & Keana - Makurdi Rd & Light brown-reddish clay soil & 080718.7 & 0084743.0 \\
\hline SS-6 & Keana Secretarat & Reddish brown clayey soil & 080750.3 & 0084748.2 \\
\hline SS-7 & Okpoya Bridge & Dark brown sandy soil & 080820.6 & 0084751.7 \\
\hline SS-8 & LG Legislative office & Dark brown sandy soil & 080851.3 & 0084703.3 \\
\hline SS-9 & Keana - Giza Rd & Slightly brownish, silty fine sandy soil & 080930.5 & 0084744.8 \\
\hline SS-10 & Keana - Giza Rd & Light brown sandy soil & 080931.4 & 0084710.5 \\
\hline SS-11 & Keana - Giza Rd & Dark brown clayey soil & 080915.4 & 0084640.7 \\
\hline SS-12 & Keana - Giza Rd & Brown, fine sand to silty clay soil & 080852.2 & 0084614.8 \\
\hline SS-13 & Keana - Giza Rd & Light brown, silty-clay soil & 080852.0 & 0084540.5 \\
\hline SS-14 & Keana - Giza Rd & Brown, silty, fine sandy soil & 080905.4 & 0084507.9 \\
\hline SS-15 & Keana - Giza Rd & Dark, brown clayey soil & 080915.0 & 0084434.9 \\
\hline SS-16 & Keana - Giza Rd & Dark, brown fine-sandy soil & 080929.8 & 0084402.6 \\
\hline SS-17 & Keana - Obi Rd & Dark brown clayey soil & 080924.8 & 0084754.9 \\
\hline SS-18 & Keana - Obi Rd & Reddish brown silty soil & 081030.6 & 0084753.4 \\
\hline SS-19 & Keana - Obi Rd & Dark brown silty soil & 081103.2 & 0084755.8 \\
\hline SS-20 & Keana - Obi Rd & Dark brown silty soil & 081136.7 & 0084754.6 \\
\hline SS-21 & Keana - Obi Rd & Light brown, very fined sandy soil & 081207.2 & 0084759.1 \\
\hline SS-22 & Keana - Obi Rd & Slightly reddish, brown fine sandy soil & 081240.3 & 0084801.7 \\
\hline SS-23 & Keana - Obi Rd & Slightly reddish, brown fine sandy soil & 081313.1 & 0084802.2 \\
\hline SS-24 & Keana - Obi Rd & Fine dark brown sandy soil & 081345.3 & 0084806.2 \\
\hline SS-25 & Keana - Obi Rd & Light brown fine sandy soil & 081431.1 & 0084815.7 \\
\hline SS-26 & Keana - Obi Rd & Light brown very fine sandy soil & 081454.4 & 0084823.0 \\
\hline SS-27 & Okpalaga - Awe Rd & Brown, silty-very fine sandy soil & 080839.4 & 0084822.8 \\
\hline SS-28 & Okpalaga - Awe Rd & brown, silty soil & 080834.2 & 0084854.5 \\
\hline SS-29 & Okpalaga - Awe Rd & Dark brown lateritic soil & 080825.6 & 0084926.9 \\
\hline SS-30 & Okpalaga - Awe Rd & Light brown clayey soil & 080820.8 & 0084959.2 \\
\hline SS-31 & Awe West & Greyish brown, calcareous lateritic soil & 080552.5 & 0090719.8 \\
\hline SS-32 & Awe West & Reddish brown, slightly lateritic soil & 080542.6 & 0090648.8 \\
\hline SS-33 & Awe South & Yellowish brown clayey soil & 080559.2 & 0090854.0 \\
\hline SS-34 & Awe South & Yellowish brown clayey soil & 080550.5 & 0090926.0 \\
\hline SS-35 & Awe South & Yellowish brown clayey soil & 080539.6 & 0090956.9 \\
\hline SS-36 & Awe South & Yellowish brown clayey soil & 080529.0 & 0091027.0 \\
\hline SS-37 & Awe South & Reddish brown clayey soil & 080520.1 & 0091058.4 \\
\hline SS-38 & Awe South & Reddish brown clayey soil & 080511.9 & 0091130.7 \\
\hline SS-39 & Awe South & Reddish brown oolitic, lateritic soil & 080505.7 & 0091214.8 \\
\hline SS -40 & Awe South & Reddish brown clayey soil & 080505.9 & 0091214.9 \\
\hline
\end{tabular}

\section{Indexes for estimating the degree of pollution Enrichment factor (EF)}

The enrichment factor (EF) was one of the standard parameters used to evaluate the level of soil contamination. The EF was calculated with respect to the local background value (Martinez-Martinez et al., 2013).

$$
\mathrm{EF}=\frac{(\text { metal })_{\text {sample }}}{(\text { metal })_{\text {background }}}
$$

Msample and Mbackground are the concentrations of the investigated elements in the sample and crustal materials (background), respectively. For this study, average abundance of trace elements in crustal (soil) materials (Levinson, 1974) were used as background values (Table 2). The assessment criteria are generally based on the EF values, as proposed by Martinez-Martinez et al. (2013). They had proposed five contamination categories from slight $(<2)$ to excessive contamination $(>16)$. Geoaccumulation index (Igeo) The geo- 
accumulation index (Igeo), as proposed by Muller 1981, allows for estimation of the enrichment of Msample and Mbackground are the concentrations of the investigated elements in the sample and crustal materials (background), respectively. For this study, average abundance of trace elements in crustal (soil) materials (Levinson, 1974) were used as background values (Table 2). The assessment criteria are generally based on the EF values, as proposed by Martinez-Martinez et al. (2013). They had proposed five contamination categories from slight $(<2)$ to excessive contamination $(>16)$.

\section{Geoaccumulation index (Igeo)}

The geo-accumulation index (Igeo), as proposed by Muller 1981, allows for estimation of the enrichment of metal concentrations above background concentrations in terrestrial, aquatic as well as marine environments (Tijani et al., 2004; Lar et al., 2013). Igeo is expressed using the equation below.

\begin{tabular}{|c|c|c|c|c|c|c|c|c|c|}
\hline Sample ID & Mo & $\mathrm{Zn}$ & As & $\mathrm{Pb}$ & Co & $\mathrm{Cr}$ & $\mathrm{Cu}$ & $\mathrm{Ba}$ & $\mathrm{Ni}$ \\
\hline 1 & 0 & 1410 & 0 & 73.01 & 111.4 & 89.18 & 71.09 & 60.23 & 53.73 \\
\hline 2 & 0 & 144 & 0 & 23.34 & 6.54 & 111.2 & 16.49 & 218.7 & 13.72 \\
\hline 3 & 0 & 0 & 0 & 129.6 & 104 & 9879 & 80.97 & 138.3 & 7322 \\
\hline 4 & 0 & 851.8 & 49.99 & 26.31 & 4.51 & 40.74 & 14.26 & 146 & 7.38 \\
\hline 5 & 0 & 1854 & 0 & 61.68 & 9.53 & 167 & 40.19 & 124.9 & 21.9 \\
\hline 6 & 0 & 1255 & 16.54 & 46.73 & 11.29 & 84.34 & 20.22 & 956.3 & 18.62 \\
\hline 7 & 0 & 990.4 & 0 & 14.7 & 31.36 & 74.54 & 25.62 & 227.2 & 53.84 \\
\hline 8 & 0 & 1998 & 71.2 & 66.92 & 10.39 & 233.9 & 35.16 & 36.87 & 155.6 \\
\hline 9 & 6.54 & 1617 & 57.01 & 28 & 2.92 & 15.42 & 9.09 & 99.31 & 7.97 \\
\hline 10 & 0 & 644.2 & 14.29 & 33.02 & 10.44 & 42.74 & 19.07 & 313.1 & 13.33 \\
\hline 11 & 0 & 2590 & 75.99 & 63.1 & 8.01 & 126.8 & 20.47 & 44.72 & 15.76 \\
\hline 12 & 2.21 & 1088 & 79 & 27.1 & 4.18 & 26.57 & 5.53 & 41.96 & 7.01 \\
\hline 13 & 0 & 479.8 & 14.28 & 17.47 & 1.34 & 33.29 & 6.91 & 500.5 & 6.06 \\
\hline 14 & 0 & 2732 & 213.1 & 121.4 & 6.41 & 50.03 & 37.16 & 64.68 & 14.37 \\
\hline 15 & 9.66 & 1592 & 123.8 & 36.5 & 3.88 & 23.11 & 10.95 & 2270.9 & 6.66 \\
\hline 16 & 0 & 763.8 & 4.7 & 37.49 & 11.04 & 55.54 & 18.65 & 61.83 & 21.95 \\
\hline 17 & 1.48 & 1271 & 101.2 & 25.04 & 4.15 & 24.8 & 7.65 & 58.3 & 4.99 \\
\hline 18 & 1.5 & 755.1 & 15.44 & 20.83 & 7.1 & 28.83 & 10.78 & 71.7 & 7.47 \\
\hline 19 & 7.85 & 1471 & 66.6 & 20.59 & 2.89 & 21.86 & 5.64 & 104.7 & 13.78 \\
\hline 20 & 11.4 & 2281 & 102.2 & 64.95 & 4.34 & 45.32 & 31.41 & 76.57 & 12.43 \\
\hline 21 & 0 & 699.2 & 54.29 & 23.49 & 3.16 & 24.84 & 9.2 & 42.19 & 7.56 \\
\hline 22 & 7.08 & 1093 & 94.19 & 18.57 & 3.75 & 25.48 & 5.03 & 81.39 & 5.04 \\
\hline 23 & 0 & 623.9 & 30.14 & 23.82 & 2.1 & 28.31 & 6.19 & 101.4 & 6.87 \\
\hline 24 & 0 & 0 & 78.42 & 60.5 & 12.1 & 953.5 & 26.25 & 78.51 & 633.2 \\
\hline 25 & 5.4 & 1203 & 54.27 & 24.61 & 4.84 & 18.84 & 6.97 & 136.1 & 7.45 \\
\hline 26 & 0 & 436.6 & 13.99 & 27.97 & 10.25 & 58.74 & 13.75 & 60.45 & 11.6 \\
\hline 27 & 0 & 782.6 & 85.49 & 25.25 & 5.42 & 49.08 & 8.55 & 212.2 & 10.94 \\
\hline 28 & 0 & 2934 & 0 & 3.46 & 16.41 & 127.6 & 72.05 & 59.57 & 107.8 \\
\hline 29 & 0 & 670.1 & 5.91 & 25.14 & 6.06 & 50.31 & 11.08 & 60.1 & 10.34 \\
\hline 30 & 0 & 1066 & 15.94 & 28.98 & 5.93 & 94.68 & 15.17 & 435.1 & 15.96 \\
\hline 31 & 0 & 310.9 & 0 & 18.84 & 6.84 & 66.46 & 14.89 & 117.1 & 11.01 \\
\hline 32 & 0 & 2480 & 0 & 152.6 & 72.83 & 114.2 & 48.89 & 2343 & 124.7 \\
\hline 33 & 0 & 303.5 & 0 & 51.07 & 37.42 & 190.3 & 42.1 & 489.2 & 64.88 \\
\hline 34 & 10.26 & 504.9 & 132.8 & 36.44 & 6.81 & 7.3 & 6.7 & 93.5 & 17.66 \\
\hline 35 & 0 & 465.3 & 18.64 & 17.93 & 10.2 & 68.96 & 8.29 & 79.4 & 7.32 \\
\hline 36 & 0 & 1739 & 88.27 & 56.67 & 5.39 & 61.06 & 31.12 & 181.8 & 19.81 \\
\hline 37 & 0 & 390 & 29.35 & 16.67 & 1.79 & 72.93 & 6.73 & 57.2 & 6.47 \\
\hline 38 & 0 & 1536 & 47.66 & 70.63 & 9.9 & 60.81 & 28.3 & 214.1 & 13.37 \\
\hline 39 & 0.33 & 583.3 & 65.21 & 24.95 & 4.12 & 32.65 & 6.31 & 66.61 & 5.87 \\
\hline 40 & 5.35 & 1427 & 101.1 & 56.22 & 3.85 & 64.47 & 33.67 & 103.3 & 15.19 \\
\hline Mean & 1.73 & 1125.91 & 48.02 & 42.53 & 14.62 & 333.61 & 22.21 & 265.73 & 322.04 \\
\hline Standard deviation & 3.32 & 760.19 & 48.13 & 32.23 & 24.93 & 555.07 & 19.23 & 505.01 & 1155.88 \\
\hline Background values (Levinson, 1974) & 2 & $10-300$ & 50 & $2-200$ & 40 & $5-1000$ & $2-100$ & 291 & $5-500$ \\
\hline
\end{tabular}




$$
\text { Igeo }=\log \left[\frac{\mathrm{C}_{\mathrm{m}} \text { Sample }}{\left(1.5 \times C_{\mathrm{m}} \text { Background }\right)}\right]
$$

Where $\mathrm{Cm}$ Sample is the metal concentration measured in the sample. The factor 1.5 corrects for the fluctuations of a given metal in the environment as well as very small anthropogenic influences (Martinez-Martinez et al., 2013). This method categorised the metal pollution into seven classes $(0$ to $>5)$, ranging from unpolluted to very highly polluted.

\section{Statistical analyses}

Statistical analyses were done using principal component analysis (PCA). PCA is a multivariate statistical technique that is usually used for data reduction to extract components which describe the maximum variation within the data with subsequent components, also maximising the remaining variability not captured by the preceding components (Singh et al., 2012). Each consecutive component is independent, unrelated and orthogonal to all others. PCA was used by some researchers to identify the origin of heavy metals in soil and other media (Rodriguez et al., 2009). This statistical tool allows information contained in a complex database to be simplified and to highlight the major sources influencing metal concentrations. PCA is a method that was designed to reduce a large number of correlated variables by diagonalisation of the correlation matrix of the data to a few uncorrelated principal components (Singh et al., 2012).

\section{Results}

The results of the trace elements analyses of the soil samples collected from the area are presented in Table 2. Distribution of molybdenum in the study area ranged from 0.33 to $11.40 \mathrm{ppm}$ with an average value of $1.73 \mathrm{ppm}$ while zinc ranged from 144 to $2934 \mathrm{ppm}$ with an average value of $1125.91 \mathrm{ppm}$. Arsenic values ranged from 4.70 to $213.10 \mathrm{ppm}$, with an average of $48.02 \mathrm{ppm}$. Lead values ranged between 3.46 and $152.60 \mathrm{ppm}$ with an average value of $42.53 \mathrm{ppm}$. Cobalt ranged from 1.34 to $111.40 \mathrm{ppm}$, with a mean value of $14.62 \mathrm{ppm}$. The value of chromium ranged from 7.30 to $9879 \mathrm{ppm}$ with an average value of $333.61 \mathrm{ppm}$. However, copper values ranged between 5.03 and $80.97 \mathrm{ppm}$, with an average value of 22.21 $\mathrm{ppm}$. Barium ranged from 36.87 to $2343 \mathrm{ppm}$, with a mean value of $265.73 \mathrm{ppm}$, while nickel ranged between 4.99 and $7322 \mathrm{ppm}$, with an average value of $322.04 \mathrm{ppm}$. The results obtained from the EFs in the soils showed that the soils around Awe were moderately to severely enriched in molybdenum, lead, cobalt, chromium, copper, barium and nickel (Table 3). Soils around the Keana axis of the study area were very severely enriched in zinc and arsenic (Table 3). Values obtained from the geo-accumulation index (Igeo) for soils from the Awe axis showed that the soils were unpolluted to moderately polluted with molybdenum, lead, cobalt, chromium, copper, barium and nickel (Table 3). Soils within this area showed a geo-accumulation index of 2 to 3 for zinc and arsenic, which should be considered as moderately polluted to highly polluted. The geo-accumulation indexes of molybdenum, lead, cobalt, copper and barium in soils from Keana ranged between 0 and 1 . These were classified as unpolluted to moderately polluted (Table 3 ). 
Table 3. Values of enrichment factor and geo-accumulation index for trace elements in soils of the study area.

Enrichment factor

\begin{tabular}{|c|c|c|c|}
\hline Metals & Keana & Awe & Remarks \\
\hline Mo & 12.05 & 20.10 & Very severe/excessive contamination \\
\hline $\mathrm{Zn}$ & 128.60 & 125.80 & Excessive contamination \\
\hline As & 87.66 & 154.10 & Excessive contamination \\
\hline $\mathrm{Pb}$ & 8.59 & 14.80 & Very severe contamination \\
\hline Co & 7.65 & 9.20 & Severe/very severe contamination \\
\hline $\mathrm{Cr}$ & 7.04 & 9.30 & Severe/very severe contamination \\
\hline $\mathrm{Cu}$ & 6.08 & 10.00 & Severe/very severe contamination \\
\hline $\mathrm{Ba}$ & 6.01 & 2.90 & Severe/moderate contamination \\
\hline \multirow[t]{3}{*}{$\mathrm{Ni}$} & 4.30 & 6.60 & Moderate/severe contamination \\
\hline & \multicolumn{2}{|c|}{$\begin{array}{c}\text { Geo- } \\
\text { accumulation } \\
\text { index }\end{array}$} & \\
\hline & Keana & Awe & \\
\hline Mo & 0.18 & 0.17 & Unpolluted to moderately polluted \\
\hline $\mathrm{Zn}$ & 3.81 & 3.28 & Strongly polluted \\
\hline As & 1.86 & 2.33 & Moderately/strongly polluted \\
\hline $\mathrm{Pb}$ & 0.39 & 0.35 & Unpolluted to moderately polluted \\
\hline Co & 0.55 & 0.37 & Unpolluted to moderately polluted \\
\hline $\mathrm{Cr}$ & 1.91 & 0.35 & Moderately polluted/unpolluted \\
\hline $\mathrm{Cu}$ & 0.74 & 0.30 & Unpolluted to moderately polluted \\
\hline $\mathrm{Ba}$ & 0.14 & 0.14 & Unpolluted \\
\hline $\mathrm{Ni}$ & 2.95 & 0.24 & Highly polluted \\
\hline
\end{tabular}

The values for geo-accumulation indexes for zinc and arsenic in soils from Keana ranged from 1.86 to 3.81, which should be considered as moderately to strongly polluted (Table 3). The results of the PCA are shown in Table 4. Three components describe the distribution patterns of trace element concentrations in the soils. These components explain the sum of the variance using the nine variables in the analysis. The first three principal components accounted for $63.29 \%$ of total variance and the variances of component 1, component 2 and component 3 are 29.56, 48.35 and 63.29\%, respectively (Table 4). Component 1 has very strong loadings of chromium, nickel and a positive loading of cobalt. Nickel and cobalt belong to the siderophile elements. They constitute part of the main rock forming minerals. 
Component 2 loadings on copper and zinc exceeded 0.74 while lead has a loading of 0.54 (Table 4). Component 3 has strong loadings of arsenic and molybdenum. It also has a strong negative loading of -0.45 for copper.

Table 4. Principal components of trace elements in soils.

Variables Component 1 Component 2 Component 3 Commonalities

\begin{tabular}{|c|c|c|c|c|}
\hline $\mathrm{Cr}$ & 0.99 & & & 0.98 \\
\hline $\mathrm{Ni}$ & 0.99 & & & 0.98 \\
\hline $\mathrm{Zn}$ & & 0.82 & & 0.84 \\
\hline $\mathrm{Cu}$ & & 0.75 & -0.45 & 0.79 \\
\hline As & & & 0.81 & 0.92 \\
\hline Mo & & & 0.73 & 0.74 \\
\hline $\mathrm{Ba}$ & & & & 0.65 \\
\hline $\mathrm{Pb}$ & & 0.54 & & 0.86 \\
\hline Co & 0.42 & & & 0.86 \\
\hline EV & 3.55 & 2.26 & 1.79 & \\
\hline VAR\% & 29.56 & 18.79 & 14.94 & \\
\hline CVAR\% & 29.56 & 48.35 & 63.29 & \\
\hline
\end{tabular}

\section{Discussion}

This present study focuses on the trace element geochemistry of a mining area; therefore the results are compared to existing data from similar areas. Research in the neighbouring galena mining geographical area at New Zurak, central Nigeria, comprising Cretaceous sediments with igneous intrusions, indicated a similar pattern of trace element distribution in soils of the area (Lar et al., 2013). The mean highest concentration recorded in the soil was for zinc followed by barium, chromium, nickel, strontium, arsenic, lead, copper, and the minimum concentration was observed for molybdenum, which was at variance with the result reported by Gupta et al. (2008). Gupta et al. (2008) reported nickel as the trace element with the highest concentration and lead had the minimum concentration in the soils of Titagarh, West Bengal, India. The mean zinc content in soils (1125.91 ppm) reported by Gupta et al. (2008) was higher than the value of 38.35 ppm obtained in Allahabad, India (Yadav et al., 2013). There was significant zinc pollution in soils around the derelict Enyigba mines in southeastern Nigeria (Ezeh et al., 2007). The concentration of zinc in the soils of the study by Ezeh et al. (2007) was similar to the levels reported in the present study and others (Ezeh \& Anike, 2009; Igwe et al., 2014). Liu et al. (2005) reported that the mean concentrations of lead, arsenic and cadmium in the soils of Chenzhou City in South China were 751.98 ppm, $459.02 \mathrm{ppm}$ and $6.77 \mathrm{ppm}$, respectively. The results of Liu et al. (2005) are 
in disagreement with those of the present study and others (Gupta et al., 2008; Guo et al., 2013). The natural lead content in soils stems from parent rocks and lead-zinc mineralisation. Its abundance in soils is a function of clay fraction content. The overall mean value of lead for different soils in the USA and India has been calculated to be on average 25 ppm (Kabata-Pendias \& Pendias, 2001). The mean lead concentration value in the present study was at variance with the values reported by Kabata-Pendias \& Pendias (2001). Ezeh et al. (2009), from their research on the mining district of Enyigba in southeastern Nigeria, found that lead constituted a polluting metal in the entire area. The concentration of lead in the soils of the Keana-Awe Brine-Fields was in disagreement with their study. This difference could be explained by the nature of the parent materials from which the soils were derived or the mineralised lead-zinc lodes in Enyigba, southeastern Nigeria. The mean chromium content in soils was $333.61 \mathrm{ppm}$. It fell within the normal values in the natural environment (Eichenberger \& Chen 1982). These researchers reported a value of 5- $300 \mathrm{ppm}$ for chromium in all soils in the Mississipi River, USA. Chromium content in soils is usually determined by its abundance in the parent material and it was more concentrated in soils derived from argillaceous rocks than arenaceous rocks (Kabata-Pendias \& Pendias, 2001). The soils of the Keana-Awe brine-fields were derived from arenaceous rocks in the area. Barium is concentrated in the soils of the study area with a mean concentration of 265.73 ppm. Barium is an element with a lithophilic affinity and is usually concentrated in acidic igneous rock on weathering; it adheres to clay fractions (Finkelman, 1999). The mean nickel concentration in soils of the area was $322.04 \mathrm{ppm}$, which is in agreement with the values reported by Siebielic \& Chaney (2006). The status of nickel in soils is dependent on its content in parent rocks. However, the concentration of nickel in soils reflects the additional impact of either soilforming processes or pollution. It was observed that there were higher levels of nickel in cultivated areas than uncultivated areas. Kadunas et al. (1999) reported that the global average values of molybdenum in soils ranged from 1.50 to $5.87 \mathrm{ppm}$. This range of global molybdenum concentration is consistent with the values obtained from the study areas of $1.73 \mathrm{ppm}$. The presence of molybdenum in appreciable amounts in the soil was due to its ability to form oxyanions and its high affinity for sulphur and related elements under reducing conditions (Sallau, 2015). It readily co-precipitates in the presence of organic matter and calcium carbonate, alongside iron, manganese and other elements such as copper, zinc and lead. The EF values suggested that the soils at Keana were severely enriched in cobalt, chromium, copper, barium and nickel; very severely enriched in molybdenum and lead; excessively enriched in arsenic and zinc. The extreme values of zinc and arsenic presented in this study are in agreement with research on potentially harmful elements that are associated with galena mining at New Zurak, Nigeria (Lar et al., 2013). The Awe soils were very severely enriched in lead, cobalt, chromium and copper; excessively enriched in molybdenum, zinc and arsenic; moderately enriched in barium and severely enriched in nickel. Adaikpoh et al. (2005) have reported that the soils of the Enugu coal mining area were enriched with lead, nickel, copper and zinc. In this study, we found that the soils of the areas were excessively enriched in arsenic. The mean Igeo values suggested that the soils were moderately to strongly polluted with arsenic and strongly polluted with zinc. These values were lower than those reported in the soils of New Zurak (Lar et al., 2013). The mean Igeo of chromium and nickel values in the soils of Awe were moderately to strongly polluted. 
These values were lower than those reported in the soils around the Okaba coal mine (Ameh, 2013). However, they were higher compared to the findings of Zhuang et al. (2013) in soils at Dabaoshan Mine, South China. Liu et al. (2005) identified three components in the application of PCA to show heavy metals in the soils of an intensively farmed area in Yucheng City, China. Component 1 showed a positive loading for cadmium, component 2 showed strong loadings on lead and zinc, while component 3 showed a negative loading for nickel. The strong loadings for lead and zinc in component 2 are similar to the results obtained in this study. The findings of this study are in agreement with similar research where these elements were found to be from anthropogenic sources (Chen et al., 2006). Mico et al. (2006) assessed heavy metal sources in the soils of the Mediterranean area and observed that the metals cobalt, chromium, zinc and iron were in component 1 with maximum variance. These components were considered as lithogenic components and the variabilities of these metals were determined by the parent rocks. In this study, component 1 elucidated $29.56 \%$ of total variance and had positive loadings for chromium, nickel and cobalt. The results corroborate the findings of Mico et al., (2006). Component 2 contained positive loadings for copper and zinc, while component 3 had a very strong positive loading for arsenic. These elements are related to anthropogenic activities. They could have been leached into the soils from the mining of lead and zinc in the area. A similar study carried out by Boriska et al. (2005) on potentially toxic elements in soils also drew the conclusion that copper and lead in soils are from anthropogenic sources.

\section{Conclusion}

The soils in the area of study were moderately to strongly enriched by nickel, chromium, arsenic, zinc and extremely contaminated by zinc and arsenic. The origin of these trace elements in the soils varies for each element. These include weathering of bedrock, natural oxidation of sulphide and mining of galena in the locality. The detection of these elements in concentrations above the normal values of a natural environment will ultimately rule out its utilisation for farming activities in view of the health risks involved. There is a need for research on the individual nickel, arsenic and chromium levels in order to provide baseline data on the nature of toxicity of these elements in the environment.Measures must be taken by the local miners to reduce trace element pollution of soils in order to maintain a safe and healthy environment. 


\section{References}

ADAIKPOH, E.O., NWAJEI, G.E. \& OGALA, J.E. 2005. Heavy metal concentrations in coal and sediments from River Ekulu, Nigeria. Journal of Applied Science and Environmental Management, 9: 5- 8.

AHMED, J.U. \& GANI, M.A. 2010. Heavy metal contaminations in water, soil and vegetation of the industrial area in Dhaka, Bangladesh. Environmental Monitoring Assessment, 166: 347- 357.

AMEH, E.G. 2013. Multivariate statistical analyses and enrichment of heavy metal contamination of soil around Okaba coal mine. American Eurasian Journal of Agronomy, 6: 9- 18.

BORISKA, L., VACCK, O. \& J EHLICKA, J . 2005. Principal component analysis as a tool to indicate the origin of potentially toxic elements in soils. Geoderma. 128: 289- 300.

CHEN, K., J IAO, J .J ., HUANG, J . \& HUANG, R. 2006. Multivariate statistical evaluation of trace elements in groundwater in a coastal area in Shenzhen, China. Environmental Pollution, 147: 771- 780.

EICHENBERGER, B.A. \& CHEN, K.Y. 1982. Origin and nature of selected inorganic constituents in natural waters. In Minear, R.A. \& Keith, L.H. (Eds), Water Analysis, Vol. 1: Inorganic Species. London, Academic Press. 782.

EZEH, H.N. \& ANIKE, O.L. 2009. The preliminary assessment of the pollution status of streams and artificial lakes created by mining in the mining district of Enyigba, Southeastern Nigeria, and their consequences. Global J ournal of Environmental Sciences 8(1): 41- 48.

EZEH, H.N., ANIKE, O.L. \& EGBOKA, B.C.E. 2007. The distribution of some heavy metals in soils in areas around the derelict Enyigba mines and its environmental implication. Current World Environment 2(2): 99- 106.

FINKELMAN, R.B. 1999. Trace elements in coal - environmental and health significance. Biological Trace Elements Resources 67: 197- 204.

GUO, Y.B., FENG, H., CHEN, C., JIA, C.J., XIONG, F. \& LU, Y. 2013. Heavy metal concentrations in soil and agricultural products near an industrial district. J ournal of Environmental Studies 22: 1357- 1362.

GUPTA, N., KHAN, D.K. \& SANTRA, S.C. 2008. An assessment of heavy metal contamination in vegetables grown in wastewater-irrigated areas of Titagarh, West Bengal, India. Bulletin of Environmental Contamination and Toxicology, 80: 115- 118.

IGWE, O., ADEPEHIN, E.J., IWUANYANWU, C. \& UNA, C.O. 2014. Risks associated with the mining of $\mathrm{Pb}-\mathrm{Zn}$ minerals in some parts of the southern Benue trough, Nigeria. Environmental Monitoring and Assessment DOI: 10.1007/ s10661-014-3655-3.

KABATA-PENDIAS, A. \& PENDIAS, H. 2001. Trace Elements in Soils and Plants. 3rd edn. Boca Raton, FL, CRC Press.

KADUNAS, V., BUDAVIAIUS, R., GREGORAUSKIENE, V., KATINAS, P., KLIUGIENE, E., RADZEVICIUS, A. \& TARASKIEVICIUS, R. 1999. Geochemical Atlas of Lithuania. Geological Institute.

KRISHNA, A.K., MOHAN, R. K. \& MURTHY, N.N. 2011. A multivariate statistical approach for monitoring of heavy metals in sediments: a case study from Walipalli Watershed, 
Nalgonda District, Andhra Pradesh, India. Journal of Environmental and Earth Sciences, 3: 103- 113.

LAR, U.A., NGOZI-CHIKA, C.S. \& ASHANO, E.C. 2013. Human exposure to lead and other potentially harmful elements associated with galena mining at New Zurak, central Nigeria. J ournal of African Earth Sciences, 84: 13- 19.

LEVINSON, A.A. 1974. Introduction to Exploration Geochemistry. Calgary, Applied Publication Company.

LIU, H.Y., PROBST, A. \& LIAO, B.H. 2005. Metal contamination of soils and crops affected by the Chenzhou lead/zinc mine spill Hunan, China. Science of the Total Environment, 339: 153- 166.

LOSKA, K., WIECHULA, D. \& KORUS, I. 2004. Metal contamination of farming soils affected by industry. Environment International, 30: 159- 165.

MAPANDA, F.,MANGWAYANA, E.N., NYAMANGARA, J . \& GILLER, K.E. 2005. The effect of long term irrigation using wastewater on heavy metal contents of soils under vegetables in Harare, Zimbabwe. Agricultural Ecosystem Environment, 107: 151- 165.

MARTINEZ-MARTINEZ, S., ACOSTA, J .A., CANO, F.A., CARMONA, D.M., ZORNOZA, R. \& CERDA, C. 2013. Assessment of lead and zinc contents in natural soils and tailing ponds from the Cartagena-La Union mining District, SE Spain. Journal of Geochemical Exploration, 124: 166- 175.

MICO, C., RECATALA, L., PERIS, M. \& SANCHEZ, J . 2006. Assessing heavy metals sources in agricultural soils of a European Mediterranean area by multivariate analysis. Chemosphere 65: 863- 872.

MULLER, G. 1981. Die Schwermetallbelastung der sediment des Neckars und seiner Nebenflusse: eine Bestandsaufnahme. Chemical Zeitung 105:157- 164.

NWAJ IDE, C.S. 2013. Geology of Nigeria's Sedimentary Basins, 1st edn, Lagos, CSS Bookshops Ltd.

OFFODILE, M.E. 1976. The Geology of the Middle Benue, Nigeria University of Uppsala, Uppsala, Palaeontological Institution of the University of Sweden, Special Volume 4.

RODRIGUEZ, L., RUIZ, E., ALONSO-AZCARATE, J. \& RINCON, J. 2009. Heavy metal distribution and chemical speciation in tailings and soils around a $\mathrm{Pb}-\mathrm{Zn}$ mine in Spain. J ournal of Environmental Management 90: 1106- 1116.

SALLAU, A.K. 2002. Trace Element Geochemistry of the Keana Brinefields, Nigeria. Unpublished MSc thesis, University of J os, Nigeria.

SALLAU, A .K. 2015. Environmental Assessment of Trace Element Distribution in the Keana Awe Brinefield, Middle Benue Trough, Nigeria. Unpublished PhD thesis, University of J os, Nigeria.

SIEBIELIC, G. \& CHANEY, R.L. 2006. Manganese fertilizer requirement to prevent manganese deficiency when liming to remediate Ni-phytotoxic soils. Soil Science 37: 1- 17.

SINGH, E.J.K., GUPTA, A \& SINGH, N.R. (2012). Groundwater quality in Imphal West District, Manipur, India with multivariate statistical analysis of data. Environmental Science Pollution Resources. DOI: 10.1007/S11356-012-1127-2 (accessed 15 January 2016). 
TIJ ANI, M.N., JINNO, K. \& HIROSHIRO, Y. 2004. Environmental impact of heavy metals distribution in water and sediments of Ogunpa River, Ibadan area, southwestern Nigeria. J ournal of Mining and Geology, 40: 73- 83.

YADAV, A., YADAV, P.K. \& SHUKLA, D.N. 2013. Investigation of heavy metal in soil and vegetables in urban area of Allahabad, Uttar Pradesh, India. International J ournal of Scientific and Research Publications 3: 1- 7.

ZHUANG, P., LI, Z., ZOU, B., XIA, H. \&WANG, G.I. 2013. Heavy metal contamination in soil and soybean near the Daboshan Mine, South China. Pedosphere, 23: 298- 304. 